\title{
Ixodes (Multidentatus) paranaensis n. sp. (Acari: Ixodidae) a Parasite of Streptoprocne biscutata (Sclater 1865) (Apodiformes: Apodidae) Birds in Brazil
}

\author{
Darci Moraes Barros-Battesti/ ${ }^{+}$, Márcia Arzua*, Mauro Pichorim**, James E Keirans***
}

\begin{abstract}
Laboratório de Parasitologia, Instituto Butantan, Av. Vital Brasil 1500, 05503-900 São Paulo, SP, Brasil *Museu de História Natural Capão da Imbuia, Departamento Zoológico, Curitiba, PR, Brasil **Pós-Graduação, Departamento de Zoologia, Universidade Federal do Paraná, Curitiba, PR, Brasil ***Institute of Arthropodology and Parasitology, Georgia Southern University, Statesboro, GA, USA
\end{abstract}

During an ecological study, carried out between 1994 and 1996 with Streptoprocne biscutata (Sclater) (Apodiformes: Apodidae) birds, that inhabit caves in the Quatro Barras County, State of Paraná, Southern Brazil, a new tick species of the subgenus Multidentatus was observed. The female, male, nymph, and larva of Ixodes (Multidentatus) paranaensis $n$. sp., are described. Of the 12 known species of the subgenus Multidentatus, only I. (M.) auritulus Neumann, 1904 and I. (M.) murreleti Cooley and Kohls, 1945 occur in the Neartic region and only I. (M.) auritulus occurs in the Neotropical region. As such, I. (M.) paranaensis $n$. sp. increases the number of species and the distribution area of the subgenus Multidentatus in the Americas.

Key words: Ixodes paranaensis - Multidentatus subgenus - tick - Streptoprocne biscutata - Apodiformes birds - Brazil

The genus Ixodes Latreille comprises 234 recognized species included in the subgenera: Afrixodes, Alloixodes, Ceratixodes, Endopalpiger, Eschatocephalus, Exopalpiger, Haemixodes, Ixodes, Ixodiopsis, Lepidixodes, Multidentatus, Partipalpiger, Pholeoixodes, Scaphixodes, Sternalixodes, and Trichotoixodes (Clifford et al. 1973, Robbins \& Keirans 1992).

In Brazil, most Ixodes species belong to the subgenus Ixodes and only one species is included in the subgenus Multidentatus. The subgenus Ixodes comprises approximately 80 species, distributed throughout all zoogeographical regions, with the exception of the Australian.

The subgenus Multidentatus, with I. laysanensis Wilson, 1964 as type species, comprises a total of 12 species and one subspecies, of which only I. auritulus Neumann, 1904 is found in Brazil. This species is observed mainly on Passeriformes and Galliformes birds (Cooley \& Kohls 1945, Kohls \& Clifford 1966, Arzua et al. 1994, Arzua \& Barros-Battesti 1999, Barros-Battesti \& Knysak 1999).

In the catalogue of Camicas et al. (1998), the genus Ixodes was partitioned into six separate genera: Ceratixodes, Eschatocephalus, Lepidixodes, Pholeoixodes, Scaphixodes and Ixodes. Those of the Brazilian species of Ixodes considered valid by these authors

This study was supported in part by the Fundação de Amparo à Pesquisa do Estado de São Paulo through project Biota-Fapesp 99/05446-8 to DMBB, and in part by the Conselho Nacional de Desenvolvimento Científico e Tecnológico-CNPq. Portions of this research were conducted under National Institute of Allergy and Infectious Diseases, grant AI 40729 to JEK. ${ }^{+}$Corresponding author. Fax: +55-11-3726.1505. E-mail: dbattest@usp.br

Received 18 June 2002

Accepted 26 September 2002 were included in the subgenus Amerixodes, except for $I$. aragaoi Fonseca, 1935. This was placed in the subgenus Ixodes. I. aragaoi was considered a junior synonym of $I$. affinis Neumann, 1899 by some authors (Cooley \& Kohls 1945, Fairchild et al. 1966) but is presented as a valid species by Camicas et al. (1998). Also, in this catalogue, $I$. (M.) auritulus was transferred to the genus Scaphixodes. Nevertheless, being a very recent classification, and not universally accepted, for the purposes of this paper we continue to adopt the nomenclature used by Clifford et al. (1973), Oliver (1989), Keirans (1992), Klompen et al. (1996).

According to Clifford et al. (1973), the main characteristics of the subgenus Multidentatus are best observed in females. The hypostomal teeth are present in large numbers and distributed in $5 / 5$ or even $6 / 6$ rows. This dental formula is uncommon in Ixodes. Most Multidentatus species present external retrograde spurs on the female coxae. These are also frequent in immature stages. The porose areas are very large, depressed and are not fused, despite being close together or almost contiguous.

\section{MATERIALS AND METHODS}

Between the years of 1994 and 1996, the study of the reproduction of Streptoprocne biscutata (Sclater 1865) (Biscutate-Swift) was conducted in a 1,250 m high, dry granite cave, located at the Morro Anhangava, Quatro Barras County, State of Paraná, Brazil (25⒉' S, 48 ${ }^{\circ} 58^{\prime} \mathrm{W}$ ) (Pichorim 1998). This region is the occidental part of the "Serra do Mar" Mountain formation located in the State of Paraná. Maximum altitude is 1,420 m and the predominant vegetation is ombrophilic dense mountain Forest (Veloso et al. 1991). In addition to monitoring nests and nestlings every two days during the reproductive season, field work consisted of ringing (marking) of adult birds with metallic rings, supplied by Cemave-Ibama (Centro de Pesquisas para a Conservação das Aves Silvestres). 
Birds were captured when leaving the cave during the day, with a hand net. After inspection, the birds were released in the environment. Inside the cave was found a total of 58 nests, which were built in 25 preferred sites. During this ecological study, the presence of a new tick species, belonging to the subgenus Multidentatus, was observed on hosts and nests. This species was here described and named $I$. (M.) paranaensis $\mathrm{n}$. $\mathrm{sp}$. In addition it was compared to it's closest relative $I$. (M.) auritulus Neumann, 1904. Specimens of I. auritulus were collected on Turdus rufiventris birds (Passeriformes: Turdidae) from Curitiba County, State of Paraná, between 1990 and 1995 (Arzua \& Barros-Battesti 1999).

All ticks were collected and stored in glass vials in $70 \%$ alcohol, and carried to the Parasitology Laboratory of the Museum of Natural History Capão de Imbuia, where they were identified. The larval specimens were prepared for optical microscopy according to Famadas et al. (1996), and four females and four nymphs were processed for scanning electron microscopy according to the method devised by Keirans et al. (1976). All material was examined and measured under a light microscope. All measurements are in millimeters; the average is followed by the standard deviation and by the range in parenthesis. The male specimen and two larvae were rendered by pen and ink illustration, using Leica MZ 12 stereomicroscope and Zeiss MC 80 DX optical microscope, respectively. Larval chaetotaxic terminology is that of Clifford and Anastos (1960). The scanning electron micrographs were obtained with an electron scanning microscope JEOL (JSM 840A) from the Electron Microscopy Lab, Departamento de Física Geral, Instituto de Física, Universidade de São Paulo (USP).

\section{RESULTS}

A total of 150 specimens of S. biscutata was studied, and from these 29 specimens of ticks were collected. Of 21 monitored young birds, only 6 were infested by 8 nymphs and 2 larvae, primarily on the head and tarsi. All infested young were less than 16 days of age. The remaining ticks, 10 females and 8 nymphs, were collected on adult birds ( $\mathrm{N}$ $=15$ ). A single male tick was collected during the study period, not on the host, but in the host's nest.

\section{Ixodes (Multidentatus) paranaensis $\mathrm{n}$. $\mathrm{sp}$.} (Figs 1-23)

Types - Holotype female, from Morro do Anhangava, Serra da Baitaca, Quatro Barras, State of Paraná ( $25^{\circ} 22^{\prime}$ 'S, $48^{\circ} 58^{\prime}$ W), Nov. 30, 1994, M. Pichorim, deposited in the Acari collection of Museu de Historia Natural Capão da Imbuia (MHNCI 615). Allotype male, from the same locality as holotype, Aug. 18, 1994, M. Pichorim, deposited in MHNCI 629.

Paratypes - 2 females and 3 nymphs, Dec. 12, 1994, M. Pichorim (MHNCI 616); 2 larvae, Sep. 15, 1995, M. Pichorim (MHNCI 625); 1 nymph, Aug. 11, 1994, M. Pichorim (MHNCI 613); 1 nymph, Feb. 23, 1995, M. Pichorim (MHNCI 630) was deposited in the Acari Collection of Zoological Museum of the Moscow, Russia; 1 female, Feb. 23, 1995, M. Pichorim (MHNCI 627) and 1 nymph, Jan. 19, 1995, M. Pichorim (MHNCI 628) were deposited in the
Acari Collection of Instituto Butantan, State of São Paulo; 1 female and 1 nymph, Aug. 12, 1994, M. Pichorim (MHNCI 612) were deposited in the United States National Tick Collection, Georgia Southern University, Statesboro, U.A.

Diagnosis - Female with an internal projection on papal segment I and strong spurs on the trochanters of the legs; porose areas oval and close together; cornua and auriculae short; semi-oval spiracular plate with a large number of goblets; a single spur on coxae II-IV; long setae on the dorsal and ventral idiosoma. Male with spinose setae on the palpi; smooth scutum with deep punctuations in the median region and along the lateral margins, and distinct pseudoscutum; a short internal spur on coxae IV; jugular plates well defined. Nymph with an internal projection on papal segment I; internal spurs present on coxae I and absent on coxae II-IV; strong spurs on the trochanters of the legs; scutal surface smooth; basis capituli dorsal straight; cornua absent; auriculae short; hypostome with dental formula essentially $3 / 3,2 / 2$ near base, $4 / 4$ at the corona. Larva with a short internal projection on papal segment I; hypostome $2 / 2$ near the basis to midlenght, $3 / 3$ to the apex; trochanters lacking spurs.

Female (Figs 1-7): four specimens measured. Idiosoma: dorsal surface non striated, with numerous setae.

Length from scapular apices to posterior body margin 2.972 \pm 0.216 (2.754-3.201); greatest width $1.967 \pm 0,116$ (1.8332.101). Scutum (Fig. 1) $1.408 \pm 0.030$ (1.382-1.442) long; $1.153 \pm 0.022$ (1.122-1.171) broad, elongate-oval, broadly rounded posteriorly, widest at about mid-length; scapulae much reduced. Cervical grooves short, converging slightly anteriorly then diverging ceasing before the maximum width of the scutum, setae few, short most evident on anterolateral margins; lateral carinae absent.

Ventral surface with few setae. Genital aperture at level of coxae III. Spiracular plates (Fig. 5) semi-oval; dorsoventral plane $0.394 \pm 0.019(0.382-0.422)$ long; $0.331 \pm$ $0.016(0.313-0.344)$ broad; approximately 15 rows of small goblets; macula eccentric.

Gnathosoma: length from palpal apices to posterior margin of basis $0.475 \pm 0.051$ (0.423-0.542). Basis capituli 0.598 $\pm 0.017(0.583-0.622)$ broad; posterior margin slightly convex, cornua short, with rounded margins (Fig. 6). Porose areas ovoid, well delineated, slightly separated. Basis capituli ventrally (Fig. 2) with mesoposterior margin slightly convex; transverse suture apparent. Length from suture to basis $0.150 \pm 0.010(0.141-0.163)$; posterior lateral margin slightly rounded. Auriculae short $0.460 \pm 0.008$ (0.453-0.471). Palpi $0.331 \pm 0.010$ (0.322-0.344) long; 0.176 $\pm 0.013(0.162-0.194)$ broad; length of articles in descending order 2 (femur), 3 (genu), 1 (trochanter), 4 (tibiotarsus); article I with distinct anterior projection.

Hypostome (Fig. 4) $0.425 \pm 0.013$ (0.411-0.442) long; 0.165 \pm 0.005 (0.161-0.173) broad, apex rounded, dental formula essentially $3 / 3,2 / 2$ near base, $4 / 4$ on anterior third followed by a single $5 / 5$ row ending with $4 / 4$ at the corona; all denticles sharply pointed.

Legs: moderately long, slender; coxae I-IV smooth, each with large external spur of approximately equal size; coxae I with two setae above short internal spur; internal spurs absent on coxae II-IV; all coxae present two or three setae 

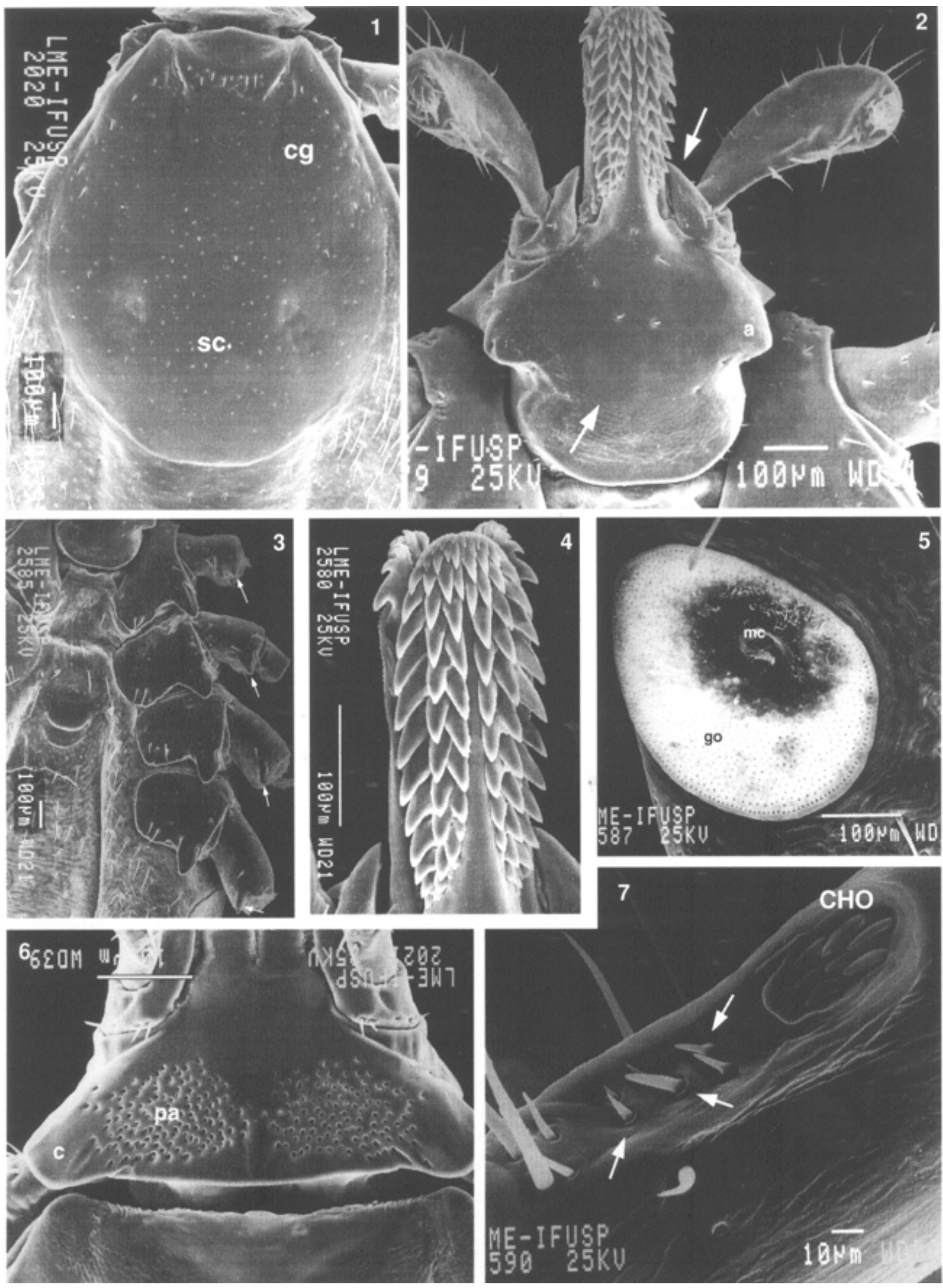

Ixodes paranaensis n. sp. female - Fig. 1: dorsal surface. Fig. 2: basis capituli ventral with transverse suture (arrowed), palpi article I with distinct anterior projection (arrowed). Fig. 3: coxae I-IV and trochanters with strong spurs (arrowed). Fig. 4: hypostome. Fig. 5: spiracular plate. Fig. 6: basis capituli dorsal. Fig. 7: Haller's organ and pre-halleral setae (arrowed); a: auriculae, c: cornua, cg: cervical grooves, CHO: capsule of Haller's organ, go: goblets, mc: macula, pa: porose areas, sc: scutum 
on internal margin (Fig. 3). Trochanters with strong spurs. Tarsus I 0.633 $\pm 0,013$ (0.615-0.642); metatarsus I 0.374 \pm 0.009 (0.362-0.381); tarsus IV $0.557 \pm 0.005$ (0.552-0.562); metatarsus IV $0.345 \pm 0.015$ (0.333-0.363). Haller's organ as shown in Fig. 7. Anal groove anteriorly rounded parallel sided diverging slightly posteriorly.

Male (Figs 8-12): a single specimen presenting posteroventral anomaly, in the genito-anal, adanal, epimeral and anal plates.

Idiosoma (Fig. 8): length from scapular apices to posterior body margin 2.542 long, 1.921 broad. Scutum oval, convex, shining, brown, length 2.223; breadth 1.624, with few deep punctuations distributed irregularly along median area and lateral margins; setae few and small. Scapulae slightly rounded. Lateral carinae absent. Cervical grooves shallow. Venter (Fig. 9) subrectangular jugular plates internal to coxae I. Pregenital plate subhexagonal, ill-defined, with anterolateral margins concave and posterolateral margins convex. Median plate length 1.423. anterior breadth 0.624 , posterior breadth 1.044. Despite the anomaly, adanal plates slightly wider anteriorly. Anal plate rounded anteriorly, parallel sided narrowing along the terminal third and diverging slightly posteriorly. All plates with small punctations. Epimeral plate (ventral view) deformed on the left side due to the anomaly, right side sbtriangular. Genital orifice between coxae II and III. Spiracular plate ovoid; macula almost central (Fig. 10). Gnathosoma (Fig. 11): length from palpal apices to posterior margin of basis 0.482 . Basis capituli dorsally 0.314 broad, cornua absent. Ventrally with two transverse ridges, capituli narrowing from the second ridge to the straight posterior margin; postero-lateral margins rounded. Palpi short, broad with many setae spinose; article I (trochanter) with strong meso-ventral ridge, length 0.113 , breadth 0.093 , articles II (femur) and III (genu) fused, length 0.194, breadth 0.162 (on article III apex). Hypostome short, broad and bilobed, length 0.203 , breadth 0.153 ; dental formula $3 /$ 3 on apical third, increasing to $5 / 5$ in median region and diminishing gradually towards the base; denticles blunt. Legs: moderate in size; all coxae with small external spur; internal spurs absent on coxae I-III, postero-internal marginal salience on coxae IV. Trochanters without spurs. Tarsus I with numerous setae 0.682 long, metatarsus I 0.604; tarsus IV 0.483 long and metatarsus IV 0.224 (Fig. 12). Haller's organ in shallow depression with no apparent capsule.

Nymph (Figs 13-18): measurements are given from three unengorged specimens and one engorged specimen.

Idiosoma (Fig. 13): length from scapular apices to posterior body margin $1.559 \pm 0.390$ (1.272-2.122); breadth 1.217 \pm 0.217 (0.950-1.473). Scutum (Fig. 14) $0.643 \pm 0.045$ (0.6100.710 ) long; $0.577 \pm 0.057$ (0.541-0.662) broad, elongateoval,broadly rounded behind, widest at about midlength; scapulae much reduced. Cervical grooves short, converging slightly anteriorly then diverging ceasing before the maximum width of the scutum; lateral carinae absent. Scutal surface smooth with few setae or punctuations. Spiracular plates (Fig. 15) almost rounded; dorsoventral plane $0.156 \pm 0.013$ (0.141-0.173) long; $0.137 \pm 0.017$ (0.121-0.152) broad; approximately 6 rows of goblets; macula eccentric.
Gnathosoma: length from palpal apices to posterior margin of basis $0.287 \pm 0.025$ (0.261-0.321). Basis capituli 0.300 \pm 0.021 (0.281-0.323) broad; posterior margin straight, cornua absent. Basis capituli ventrally mesoposterior margin slightly rounded (Fig. 16); transverse suture apparent near auriculae. Length from suture to basis $0.054 \pm 0.006$ (0.047-0.062); posterior lateral margin slightly rounded. Auriculae short, distance between them $0.212 \pm 0.008$ (0.202-0.222). Palpi $0.219 \pm 0.006$ (0.210-0.223) long; 0.067 $\pm 0.005(0.062-0.072)$ broad; length of articles in descending order 2, 3, 1, 4; article I (trochanter) with distinct anterior projection. Hypostome $0.305 \pm 0.016$ (0.291-0.323) long; $0.113 \pm 0.002(0.111-0.115)$ broad, apex rounded, dental formula essentially $3 / 3,2 / 2$ near base, $4 / 4$ at the corona; all denticles sharply pointed.

Legs: moderately elongate, slender; coxae I-IV smooth (Fig. 17), each with large external spur of approximately equal size, the most pointed on coxa I; coxae I-IV with one setae above external spur; internal spurs present on coxae I and absent on coxae II-IV; all coxae present one setae on internal margin and one setae above internal spurs. Trochanters with strong spurs. Tarsus and metatarsus I 0.592 \pm 0.031 (0.552-0.621) long; tarsus and metatarsus IV 0.942 \pm 0.014 (0.922-0.952) long. Haller's organ as shown on figure (Fig. 18). Anal groove anteriorly rounded parallel sided diverging slightly posteriorly.

Larva (Figs 19-23): measurements are given from a partially engorged specimen except for the hypostome that was taken from the other fully engorged specimen. Both specimens were slide-mounted.

Idiosoma: dorsal surface (Fig. 19). Length from apices of scapulae to posterior margin of body; 1.050 long (excluding gnathosoma); 0.872 broad broadest near midlenght. Sensila sagittiformia absent. Dorsal setae: 11 pairs; 3 pairs of central dorsals (Cd1-Cd3); 8 pairs marginal dorsals (Md1-Md8). Scutum outline subtriangular, length 0.270 along median line; breadth 0.333 ; cervical grooves extending parallel to the proximities of setae Sc3; scutal setae: short, 5 pairs (Sc1-Sc5), distance between Sc1 0.075, Sc2 0.175 , Sc3 0.060, Sc4 0.275, and Sc5 0.225. Ventral surface (Fig. 20). Setae: 13 pairs plus 1 pair on anal valves, 3 pairs of sternals, St1 below coxae I, St 2 between coxae II, and St3 between coxae III; 2 pairs of preanals (Pa1-Pa2); 5 pairs of premarginals (Pm1-Pm5); and 3 pairs of marginal ventrals setae (Mv1-Mv3). Anal grove indistinct.

Gnathosoma: length from palpal apices to posterior margin of basis 0.160 . Basis capituli dorsally (Fig. 21) with posterior margin straight, lateral margins slightly rounded 0,160 broad; cornua absent. Ventrally basis (Fig. 22) constricted posterior to midlenght, auriculae absent. Post hypostomal setae 2 pairs, distance between $\mathrm{Ph} 10,040$ and Ph2 0,030. Palpi short, blunt rounded, 0,113 long by 0,036 broad. Palpal setae: 8 setae on article IV (tibiotarsus) (Ttt18); 7 genual setae, 1 paraxial (Gp1), 2 antiaxial (Ga1- Ga2), 3 dorsal (Gd1-Gd3), 1 ventral (Gv1); 6 femoral setae, 1 paraxial (Fp1), 2 antiaxial (Fa1-Fa2), 1 dorsal (Fd1), and 2 ventral (Fv1-Fv2); 0 on article I (trochanter); palpal article I with a short anterior projection. Hypostome blunt anteriorly; length from apices to first post hypostomal seta 0,133 long; 0,046 broad in one specimen; dentition 2/2 near the 

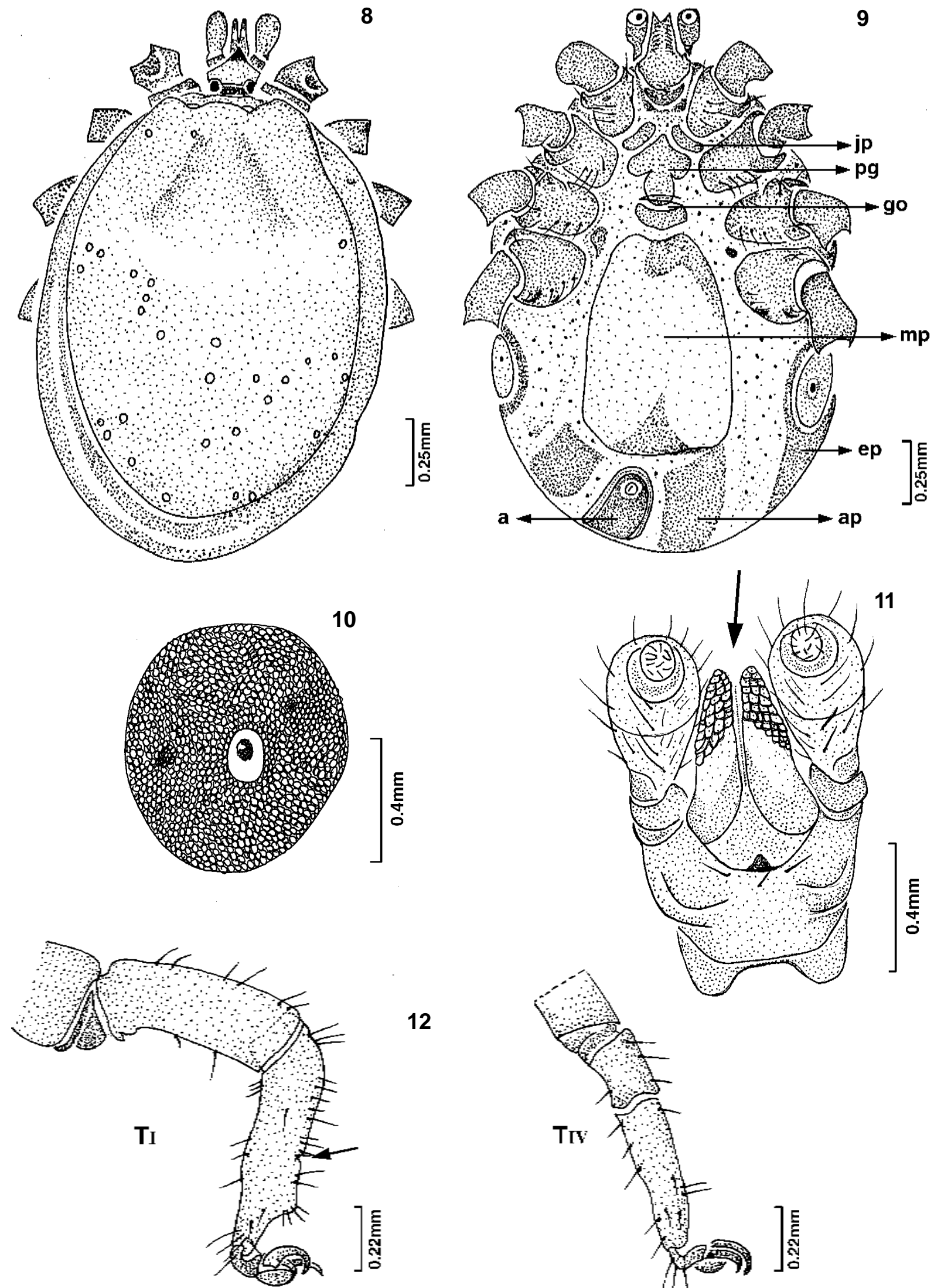

12

Ixodes paranaensis n. sp. male - Fig. 8: Idiosoma, dorsal view. Fig. 9: Idiosoma, ventral view. Fig. 1d: spiracular plate. Fig. 11: nathosoma ventral with bilobed hypostome (arrowed). Fig. 12: tarsus I (TI) with Haller's organ in shallow depression with no pparent capsule (arrowed) and IV (TIV); a: anal plate, ap: adanal plate, ep: epimeral plate, go: genital orifice, jp: jugular plates, mp: median plate, pg: pregenital plate 

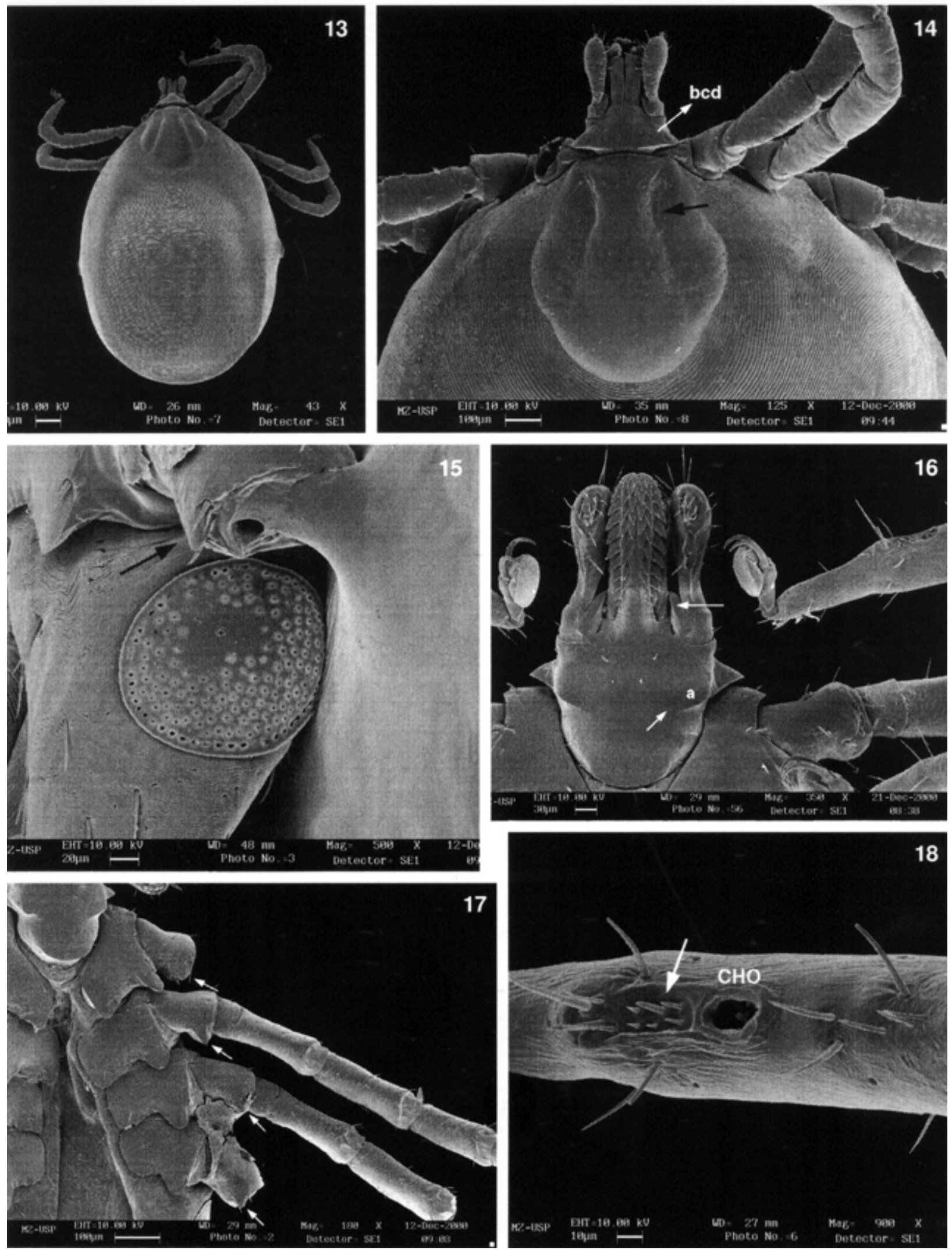

Ixodes paranaensis $\mathrm{n}$. sp. nymph - Fig. 13: idiosoma dorsal. Fig. 14: scutum with cervical grooves converging slightly anteriorly (arrowed). Fig. 15: spiracular plate and spur on the trochanter IV (arrowed). Fig. 16: basis capituli ventral with transverse suture (arrowed) and palpi article I with distinct anterior projection (arrowed). Fig. 17: coxae I-IV and spurs on the trochanters (arrowed). Fig. 18: Haller's organ and pre-halleral setae (arrowed); a: auricula, bcd: basis capituli dorsal, CHO: capsule of Haller's organ 

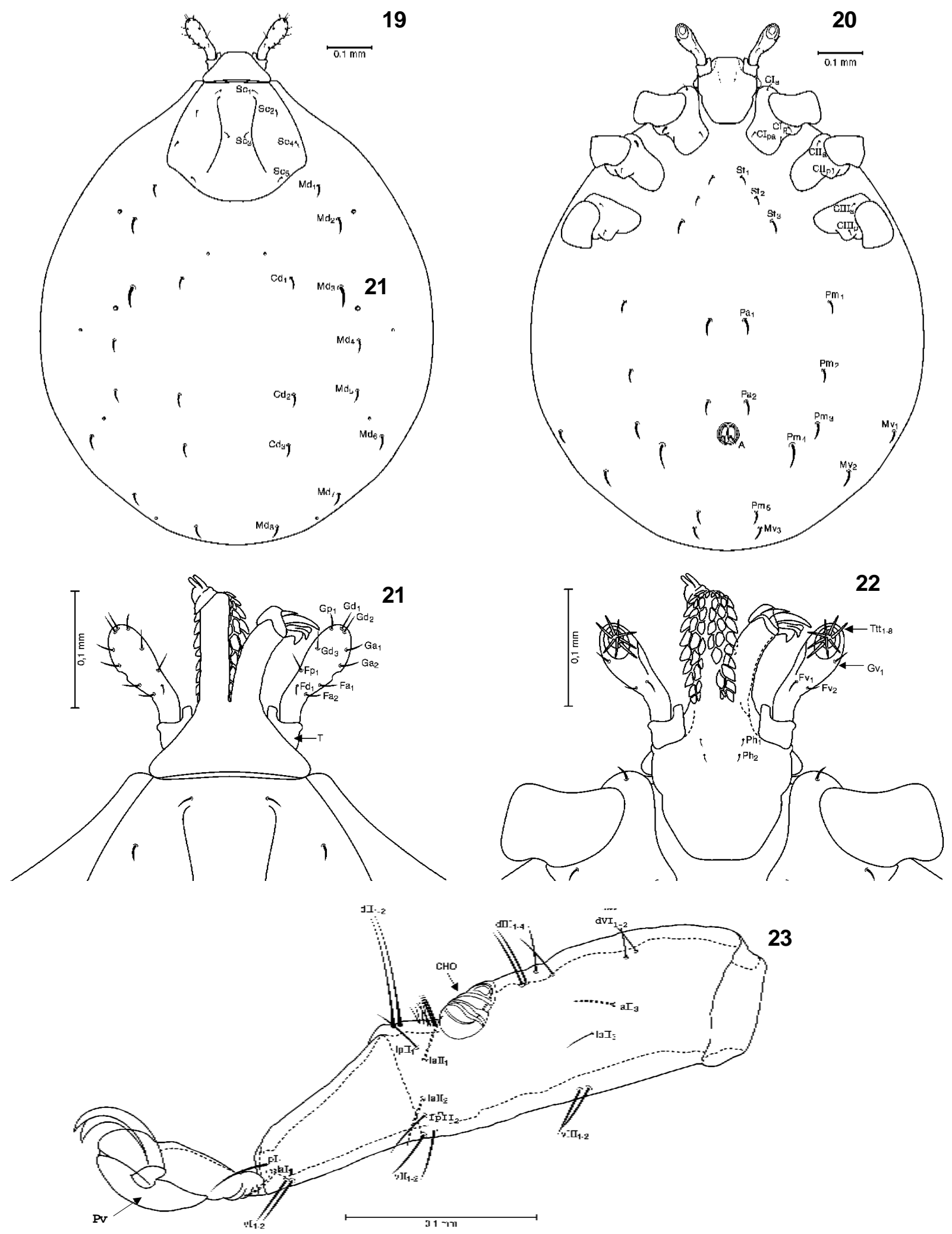

Ixodes paranaensis n. sp. larva - Fig. 19: idiosoma dorsal view. Fig. 20: idiosoma ventral view. Fig. 21: gnathosoma dorsal view. Fig. 22: gnathosoma ventral view. Fig. 23: tarsus I, lateral view. CHO: capsule of Haller's organ, pv: pulvillus, T: trochanter, A: anal, Cd: central dorsal setae, CIa: coxa I anterior, CIp: coxa I posterior, CIpa: coxa I paraxial, CIIa: coxa II anterior, CIIp: coxa II posterior, CIIIa: coxa III anterior, CIIIp: coxa III posterior, dII: dorsal (group II), dIII: dorsal (group III), dVI: dorsal (group VI), Fa: femoral antiaxial, Fd: femoral dorsal, Fp: femoral paraxial, Fv: femoral ventral, Ga: genual antiaxial, Gd: genual dorsal, Gp: genual paraxial, Gv: genual ventral, laI: lateral anterior (group I), laII: lateral anterior (group II), lpI: lateral posterior (group I), lpII: lateral posterior ( group II), Md: marginal dorsal, Mv: marginal ventral, Pa: pre-anal, Ph: post hypostomal, Pm: premarginal, Sc: scutal, St: sternal, Ttt: tibiotarsus terminal, vI: ventral (group I), vII: ventral (group II), vIII: ventral (group III). 
basis to midlenght, $3 / 3$ to the apex with a small corona of fine denticles apical; 8-9 denticles in file I, 9 in file II, and 5 in file III.

Legs: coxa I with a broadly rounded internal spur and a small, bluntly triangular external spur; definite internal spur absent but with bluntly triangular external spurs on remaining legs. Setae: 3 on coxa I, 1 anterior (CIa), 1 posterior (CIp) and 1 paraxial (CIpa); and 2 each coxae II and III (CIIa, CIIp, CIIIa, and CIIIp). Trochanters lacking spurs. Tarsus I (Fig. 23) 0,261 long, greatest width 0.077. Setae: the alignment of setae resembles that for the genus 4:4:2. Dorsal setae: group I absent. However the 4 setae pre halleral in the group II comprise 2 dorsal (dII1, dII2), and 2 lateral antiaxial (laII1) and paraxial (lpII1); the post halleral setae comprise 4 dorsal in the group III (dIII1-dIII4), absent in the groups IV and V, and 2 dorsal in the group VI (dVI1, dVI2). Ventral and lateral setae: 4 setae in group I, 2 ventral (vI1, vI2), and lateral antiaxial (laI1, lpI1); 4 setae in group II, 2 ventral (vII1, vII2), and lateral antiaxial (laII1), and paraxial (lpII1); 4 setae in group III, 2 ventral (vIII1, vIII2), and lateral antiaxial (laIII1), and paraxial (lpIII1).

Other examined material: MHNCI 614 (1N, 28/XI/ 1994); MHNCI 617 (1F, 16/XI/1994); MHNCI 618 (1F, 9/ XII/1994); MHNCI 619 (1N, 25/XI/1994); MHNCI620(1N, 30/XI/ 1994); MHNCI 621 (1F, 20/XI/1994); MHNCI 622 (1N, 12/ XII/1994); MHNCI 623 (1N, 30/XI/1994); MHNCI 624 (1F, 28/XI/1994); MHNCI626(1F, 23/X/1994); MHNCI 630 (1N, 23/II/1995); MHNCI 631 (1N, 19/I/1995); MHNCI 632 (1N, 9/XII/1994); MHNCI 633 (1N, 23/II/1995). All from the same locality of types and all collected by M Pichorim.

\section{Ixodes auritulus Neumann, 1904}

(Figs 24-30)

Ixodes thoracicus Neumann, 1899, Mem. Soc. Zool. Fr. 12: 149, figs. 22, 23, (nec Koch, 1844).

Ixodes auritulus Neumann, 1904, Arch. Parasitol. 8: 450 (nomen novem for I. thoracicus Neumann, 1899).

Original descriptions:

Female (Neumann, 1899: 149, figs. 22, 23 (as I. thoracicus) Male (Kohls \& Clifford, 1966, J. Parasitol. 52:815, figs.

20-24)

Nymph (Nuttall, 1916, Parasitology 8:314, fig. 15)

Larva (Nuttall, 1916: 314, fig. 16)

\section{Morphological notes}

In $I$. (M.) auritulus females, the porose areas are rounded and the spacing between them is large; cornua sharp (Fig. 29). Cervical grooves diverge and cease in front of the postero-lateral edge (Fig. 24). Ventrally, the posterior margin of the capitulum is almost straight and the auriculae are long and horn-shaped (Fig. 25). The prolongation of palp I reaches the center of the hypostome, as illustrated by Keirans and Clifford (1978). Dental formula $2 / 2$ basally, followed by two rows of $3 / 3$, followed by 5 rows of $4 / 4,3$ rows $5 / 5$ and ending at the corona with 1 row 6/6 (Fig. 27). Internal and external spurs present on coxae I-III; coxae IV with only an external spur, all trochanters with spurs (Fig. 26). Haller's organ very similar to that of the new species (Fig. 30). Spiracular plate semi-circular with approximately six rows of goblets and macula almost central (Fig. 28). We are not providing illustrations of the male because it is so rare, but they can be found in Kohls and Clifford (1966) and in Keirans and Clifford (1978).

\section{REMARKS}

Females of $I$. paranaensis n. sp. resemble $I$. (M.) auritulus by the presence of internal projection on papal segment I and spurs on the trochanters of the legs. However, the new species differs by the absence of internal spurs on coxae II-IV; porose areas oval and close together; cornua and auriculae short; semi-oval spiracular plate with a large number of goblets; and long setae on the dorsal and ventral surfaces of the body. The male of $I$. paranaensis, resembles $I$. (M.) auritulus, by the spinose setae on the palpi, smooth scutum, and distinct pseudoscutum but differs by the presence of deep punctuations in the median region and along the lateral margins of the scutum, and by the presence of a short internal spur on coxae IV. The jugular plates, well defined in the Ixodes paranaensis, resemble those of I. auritulus zealandicus Dumbleton, 1953. Setae on tarsus I and metatarsus I resemble those of I. kerguelenensis André \& Colas-Belcour, 1942. Nymph and larva of Ixodes paranaensis resemble that of I. auritulus. According to the morphology of I. auritulus nymph presented by Durden and Keirans (1996), it differs from the nymph of I. paranaensis in having auriculae and cornua that are short and absent, in the nymph of I. paranaensis, respectively. Furthermore, the posterior margin of the ventral capituli is straight in $I$. auritulus while it is rounded in I. paranaensis. The larva of I. paranaensis differs from the larva of I. auritulus in having hypostome $2 / 2$ near the basis to midlenght, $3 / 3$ to the apex and trochanters lacking spurs.

The presence of I. paranaensis among young hosts was low. According to Oliver (1989), special habitat selection in nidicolous tick species is a strategy for the biological cycle development. In this case, the lack of male ticks on hosts might be related to a dependence on the nest microhabitat. This could be a strategy for mating and not necessarily a direct dependence on the host, despite the parasitic specificity of females and immature forms.

The family Apodidae is amply distributed, on almost all continents (Collins 1985). Most species are tropical. Of 92 species, 23 occur in South America. The genus Streptoprocne is exclusively Neotropical and comprises the three larger species of the family. S. semicollaris is endemic to Mexico; $S$. zonaris is widely distributed in Central and South America. S. biscutata is distributed in eastern Brazil, from the State of Rio Grande do Norte to Rio Grande do Sul, extending to northeastern Argentina (Chantler \& Driessens 1995). To date, there is only one record of parasitism of Ixodes ticks on birds of the genus Streptoprocne. This record refers to the species $I$. cuernavacensis Kohls and Clifford on S. semicollaris from Mexico (Kohls \& Clifford 1966). According to Clifford et al. (1973) this species belongs to the subgenus Ixodes. However according to Camicas et al. (1998) it is not assigned to any subgenus.

Of the 12 known species of the subgenus Multidentatus, only I. (M.) auritulus and I. (M.) murreleti Cooley and Kohls, 1945, occur in the neartic region and 

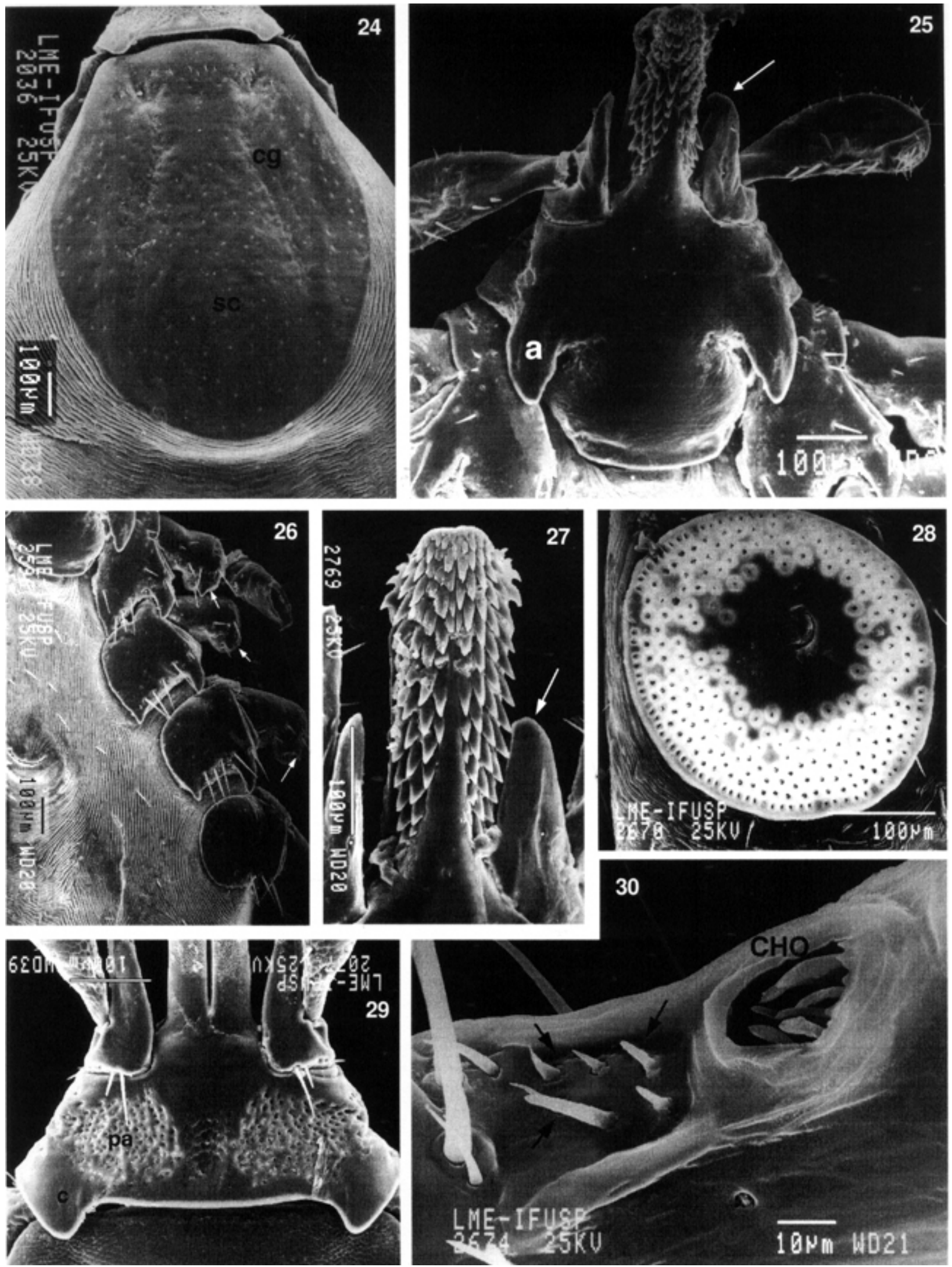

Ixodes auritulus Neumann, female - Fig. 24: idiosoma dorsal urface and scutum. Fig. 25: basis capituli ventral and palpi rticle I with strong anterior projection (arrowed). Fig. 26: coxae I-IV nd strong spurs on trochanters (arrowed). Fig. 27: hypostome nd article I (arrowed). Fig. 28: spiracular plate. Fig. 29: basis apituli dorsal. Fig. 30: Haller's organ and pre-halleral setae arrowed); a: auriculae, c: cornua, cg: cervical grooves, CHO: capsule of Haller's organ, pa: porose areas, sc: scutum 
only I. (M.) auritulus occurs in the Neotropical region (Clifford et al. 1973). As such, I. paranaensis n. sp. increases the number of species and the distribution area of the subgenus Multidentatus in the Americas.

\section{ACKNOWLEDGMENTS}

To Instituto Brasileiro de Meio Ambiente e dos Recursos Naturais Renováveis (Ibama) for permitting the capture, the handling, and the release of birds. To the members of Laboratorio de Microscopia Eletrônica, Departamento de Física Geral, Instituto de Física, Universidade de São Paulo for the technical assistance in preparing the scanning electron micrographs. To Antonio Domingos Brescovit and Cristina A Rheims, Instituto Butantan, for the critical analysis of the manuscript.

\section{REFERENCES}

Arzua M, Barros DM, Linardi PM, Botelho JR 1994. Noteworthy records of Ixodes auritulus Neumann, 1904 (Acari, Ixodida) on birds from Paraná, Southern Brazil. Mem Inst Oswaldo Cruz 89: 129.

Arzua M, Barros-Battesti DM 1999. Parasitism of Ixodes (Multidentatus) auritulus Neumann (Acari: Ixodidae) on birds from the city of Curitiba, State of Paraná, Southern Brazil. Mem Inst Oswaldo Cruz 94: 597-603.

Barros-Battesti DM, Knysak I 1999. Catalogue of the Brazilian Ixodes (Acari: Ixodidae) material in the mite collection of Instituto Butantan, São Paulo, Brazil. Pap Avulsos Zool 41: 49-57.

Camicas JL, Hervy JP, Adam F, Morel PC 1998. Les Tiques du Monde, Éditions de I'Orstom, Institut Français de Recherche Scientifique pour le Développement en Coopération, Paris, 233 pp.

Chantler P, Driessens G 1995. Swifts, a Guide to the Swifts and Treeswifts of the World, Pica Press, Sussex, 237 pp.

Clifford CM, Anastos G 1960. The use of chaetotaxy on the identification of larval ticks (Acarina: Ixodidae). J Parasitol 46: 567-578.

Clifford CM, Sonenshine DE, Keirans JE, Kohls GM 1973. Systematics of the subfamily Ixodinae (Acarina: Ixodidae). I. The subgenera of Ixodes. Ann Entomol Soc Am 66: 489500.

Collins CT 1985. Swift. In B Campbell, E Lack (eds), A Dictionary of Birds, Buteo Books, Vermillion, p. 572-574.

Cooley RA, Kohls GM 1945. The genus Ixodes in North America. Nat Inst Health Bull 184: 1-246.
Durden LA, Keirans JE 1996. Nymphs of the Genus Ixodes (Acari: Ixodidae) of the United States: Taxonomy, Identification Key, Distribution, Hosts, and Medical/Veterinary Importance, Entomological Society of America, Lanham, Maryland, $95 \mathrm{pp}$.

Famadas KM, Serra-Freire NM, Faccini JLH 1996. A note on slide-mounting technique of unfed immature stages of Amblyomma cajennense Frabricius, 1787 (Acari: Ixodidae). Mem Inst Oswaldo Cruz 91: 139-140.

Fairchild GB, Kohls GM, Tipton VJ 1966. The ticks of Panama (Acarina: Ixodoidea). In RL Wenzel, VJ Tipton (eds), Ecto parasites of Panama, Field Museum of Natural History, Chicago, p. 167-219.

Keirans JE 1992. Systematics of the Ixodida (Argasidae, Ixo didae, Nuttalliellidae): an overview and some problems. In B Fivaz, T Petney, I Horak (eds), Tick Vector Biology Medical and Veterinary Aspects, Springer, Berlin, p. 1-21.

Keirans JE, Clifford CM 1978. The genus Ixodes in the United States: a scanning electron microscope study and key to the adults. J Med Entomol (Suppl. 2): 1-149.

Keirans JE, Clifford CM, Corwin D 1976. Ixodes sigelos n. sp. (Acarina: Ixodidae), a parasite of rodents in Chile, with a method for preparing ticks for examination by scanning electron microscopy. Acarologia 18: 217-225.

Klompen JSH, Black WC IV, Keirans JE, Oliver Jr JH 1996. Evolution of ticks. Annu Rev Entomol 41: 141-161.

Kohls GM, Clifford CM 1966. Three new species of Ixodes from Mexico and description of the male of I. auritulus auritulus Neumann, I. conepati Cooley and Kohls, and I. lasallei Mendez and Ortiz (Acarina: Ixodidae). J Parasitol 52: $810-820$.

Oliver Jr JH 1989. Biology and systematics of ticks (Acari: Ixodida). Annu Rev Ecol Syst 20: 397-430.

Pichorim M 1998. Biologia Reprodutiva do Andorinhãodecoleira-falha, Streptoprocne biscutata (Sclater 1865) (Aves: Apodidae) do Morro do Anhangava, Serra do Mar Paranaense, MSc Thesis, Departamento de Zoologia, Universidade Federal do Paraná, Curitiba, 67 pp.

Robbins RG, Keirans JE 1992. Systematics and ecology of the subgenus Ixodiopsis (Acarina: Ixodidae: Ixodes). Thomas Say Found Monogr 14: 1-159.

Veloso HP, Rangel Filho ALR, Lima JCA 1991. Classificação da Vegetação Brasileira, Adaptada a um Sistema Universal, IBGE, Departamento de Recursos Naturais e Estudos Ambientais, Rio de Janeiro, 123 pp. 